Check for updates

Cite this: RSC Adv., 2019, 9, 7594

Received 5th February 2019

Accepted 25th February 2019

DOI: 10.1039/c9ra00965e

rsc.li/rsc-advances

\section{Chemical and biological study of aplysiatoxin derivatives showing inhibition of potassium channel Kv1.5†}

\author{
Yang-Hua Tang, $\$^{\text {ab }}$ Jing Wu,,$^{\mathrm{c}}$ Ting-Ting Fan, ${ }^{\mathrm{a}}$ Hui-Hui Zhang, ${ }^{a}$ Xiao-Xia Gong, ${ }^{\mathrm{a}}$ \\ Zheng-Yu Cao, ${ }^{e}$ Jian Zhang, ${ }^{* c}$ Hou-Wen Lin (D) ${ }^{* d}$ and Bing-Nan Han (DD *a
}

Three new aplysiatoxins, neo-debromoaplysiatoxin D (1), oscillatoxin E (2) and oscillatoxin $F$ (3), accompanied by four known analogues (4-7), were identified from the marine cyanobacterium Lyngbya $\mathrm{sp}$. Structural frames differ amongst these metabolites, and therefore we classified compounds 1 and 46 as aplysiatoxins as they possess 6/12/6 and 6/10/6 tricyclic ring systems featuring a macrolactone ring, and compounds 2, 3 and 7 as oscillatoxins that feature a hexane-tetrahydropyran in a spirobicyclic system. Bioactivity experiments showed that compounds 1 and 4-6 presented significant expression of phosphor-PKC $\delta$ whereas compounds 2, 5 and 7 showed the most potent blocking activity against potassium channel Kv1.5 with $\mathrm{IC}_{50}$ values of $0.79 \pm 0.032 \mu \mathrm{M}, 1.28 \pm 0.080 \mu \mathrm{M}$ and $1.47 \pm 0.138 \mu \mathrm{M}$, respectively. Molecular docking analysis supplementing the binding interaction of oscillatoxin $E$ (2) and oscillatoxin F (3) with Kv1.5 showed oscillatoxin E (2) with a strong binding affinity of $-37.645 \mathrm{kcal} \mathrm{mol}^{-1}$ and oscillatoxin $F(3)$ with a weaker affinity of $-32.217 \mathrm{kcal} \mathrm{mol}^{-1}$, further supporting the experimental data.

\section{Introduction}

Cyanotoxins, otherwise known as poisonous metabolites yielded by cyanobacteria, can be classified into neurotoxins (anatoxin-a, $\beta$-methylamino alanine), hepatotoxins (microcystins, nodularins), cytotoxins (cylindrospermopsin) and dermatotoxins (lyngbyatoxin-a, aplysiatoxins) based on their mode of action. ${ }^{1}$ The aplysiatoxins (ATXs) are a class of biologically active dermatotoxins with anti-proliferative activity, tumourpromoting properties, proinflammatory actions and antiviral activity. ${ }^{2-6}$ Initially, aplysiatoxin and debromoaplysiatoxin were obtained from the sea hare Stylocheilus longicauda, whilst further research indicated that these compounds are metabolized by cyanobacteria., 27 ATXs have been isolated from

${ }^{a}$ Research Center of Marine Biology and Natural Products, College of Life Sciences and Medicine, Zhejiang Sci-Tech University, Hangzhou 310018, China. E-mail: hanbingnan@zstu.edu.cn

${ }^{b}$ Department of Pharmacy, Graduate School, Hunan University of Chinese Medicine, Changsha 410208, People's Republic of China

'Department of Pathophysiology, Shanghai Jiaotong University, School of Medicine, Shanghai 200025, China.E-mail: jian.zhang@sjtu.edu.cn

${ }^{d}$ Research Center for Marine Drugs, State Key Laboratory of Oncogenes and Related Genes, Department of Pharmacy, Ren Ji Hospital Affiliated to Shanghai Jiao Tong University School of Medicine, Shanghai 200127, China. E-mail: franklin67@126.com 'Jiangsu Provincial Key Laboratory for TCM Evaluation and Translational Development, China Pharmaceutical University, Nanjing, China

† Electronic supplementary information (ESI) available. See DOI: 10.1039/c9ra00965e

\$ These authors contributed equally to this work. marine cyanobacteria so far. ${ }^{5-14}$ According to their structural characteristics, the early isolated ATXs were classified into three categories: aplysiatoxins possessing 6/12/6 tricyclic ring systems featuring a macrolactone ring (ABC ring) (e.g. aplysiatoxin, debromoaplysiatoxin, manauealides $\mathrm{A}-\mathrm{C}$ and oscillatoxin A); oscillatoxins featuring a hexane-tetrahydropyran of a spirobicyclic system ( $\mathrm{AB}$ ring) (oscillatoxin $\mathrm{D}$ and 30-methyloscillatoxin D); and nhatrangins featuring an opening chain (nhatrangins A and B). The main structural skeleton of ATXs (tricyclic ring systems) vary greatly, whilst their side chains, that contain aromatic rings, often remain unchanged. Our research group recently isolated two new ATXs that display rare carbon skeletons; neo-debromoaplysiatoxin A showing a 6/10/6 fusedring system which we grouped as an aplysiatoxin and neodebromoaplysiatoxin $\mathrm{B}$ with a 6/6/6 fused ring system as an oscillatoxin. In addition to this structural novelty, these compounds also exhibit excellent bioactivity with potent blocking action against potassium channel Kv1.5. ${ }^{14} \mathrm{Kv} 1.5$ has been presumed to be a pivotal target for new treatment of atrial tachyarrhythmias with minimal side effects. ${ }^{15,16}$ In pursuit of additional novel Kv1.5 inhibitors, our group isolated three new aplysiatoxins, neo-debromoaplysiatoxin D (1) and oscillatoxin E and $\mathrm{F}$ (2 and 3), and four known aplysiatoxins (4-7) from the cyanobacterium Lyngbya sp. extracted from the South China Sea (Fig. 1). Due to their structural characteristics, compounds 1 and 4-6 can be classified as aplysiatoxins, with their corresponding $\mathrm{ABC}$ ring, and 2, 3 and 7 as oscillatoxins. This report details the separation, structural elucidation and biological activity of these metabolites. Herein, we demonstrate that 

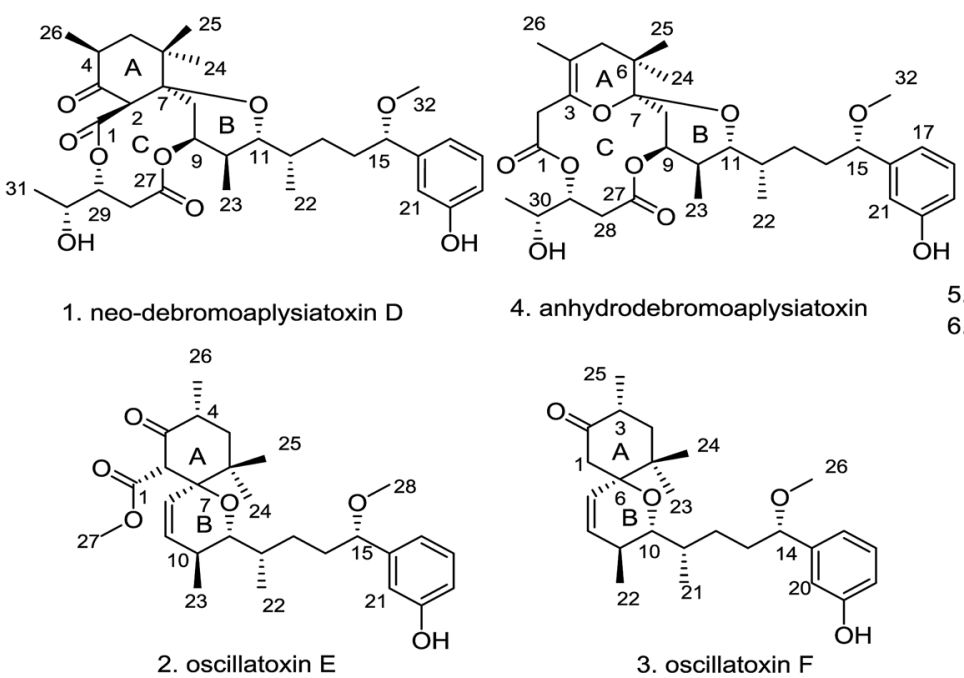

4. anhydrodebromoaplysiatoxin

5. debromoaplysiatoxin $\mathrm{R}=\mathrm{H}$

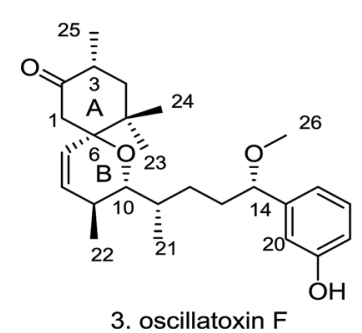

6. 3-methoxydebromoaplysiatoxin $\mathrm{R}=\mathrm{CH}_{3}$

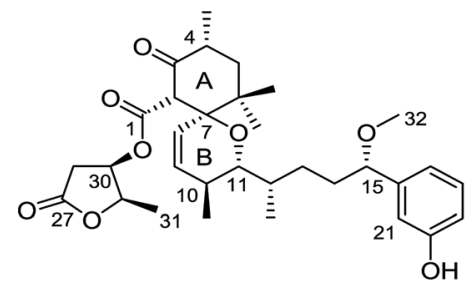

7. 30-methyloscillatoxin $D$

Fig. 1 Chemical structures of compounds 1-7.

compounds 1 and 4-6 expressed phosphor-PKC $\delta$ dramatically, but our oscillatoxins, 2, 3 and 7, lacked any activity. Importantly, selective blocking of Kv1.5 was seen to be significant for 2,5 and 7 with $\mathrm{IC}_{50}$ values of $0.79 \pm 0.032 \mu \mathrm{M}, 1.28 \pm 0.080 \mu \mathrm{M}$ and $1.47 \pm 0.138 \mu \mathrm{M}$, respectively.

\section{Results and discussion}

The cyanobacterium Lyngbya sp. was collected in the South China Sea and extracted with $\mathrm{MeOH}$ and $\mathrm{CH}_{2} \mathrm{Cl}_{2}(1: 1, \mathrm{v} / \mathrm{v})$. The extract was suspended in aqueous $\mathrm{MeOH}$ and extracted with petroleum ether, dichloromethane and ethyl acetate. To identify the main constituents of the extracts preliminary, a ${ }^{1} \mathrm{H}-\mathrm{NMR}$ method was utilized to the extracts and revealed the enrichment of aplysiatoxins in the dichloromethane extract. Sequential chromatography of dichloromethane extract on vacuum liquid chromatography (VLC) and octadecyl silica gel (ODS), followed by $\mathrm{C}_{18}$ reverse-phase HPLC, led to the isolation of seven aplysiatoxin derivatives including three new compounds, neo-debromoaplysiatoxin D (1), oscillatoxin E (2) and oscillatoxin F (3), and four known compounds (4-7). These four known structures were identified as anhydrodebromoaplysiatoxin (4), debromoaplysiatoxin (5), 3-methoxydebromoaplysiatoxin (6) and 30-methyloscillatoxin D (7) by comparing their spectroscopic data with the literature data. ${ }^{6,10,11}$

Neo-debromoaplysiatoxin D (1) was isolated as a colourless solid, with a molecular formula $\mathrm{C}_{32} \mathrm{H}_{46} \mathrm{O}_{9}$ indicating ten degrees of unsaturation was established by HRESIMS. The ${ }^{1} \mathrm{H}$ NMR spectrum uncovered the appearance of a 1,3-disubstituted aromatic ring at $\delta_{\mathrm{H}} 7.20(\mathrm{t}, J=7.8 \mathrm{~Hz}), \delta_{\mathrm{H}} 6.99(\mathrm{~m}), \delta_{\mathrm{H}} 6.88(\mathrm{~d}, J=$ $7.6 \mathrm{~Hz})$ and $\delta_{\mathrm{H}} 6.75(\mathrm{dd}, J=8.1,2.5 \mathrm{~Hz})$, four methyl doublets at $\delta_{\mathrm{H}} 1.25,1.10,0.89$ and 0.75 and three methyl singlets at $\delta_{\mathrm{H}} 3.27$, 1.02 and 0.79 . The ${ }^{13} \mathrm{C}$ and DEPT spectrum of 1 displayed seven quaternary carbons including one keto carbon $\left(\delta_{\mathrm{C}} 211.6\right)$, two carbonyl carbons $\left(\delta_{\mathrm{C}} 170.9\right.$ and 169.8$)$ and two aromatic carbons $\left(\delta_{\mathrm{C}} 156.6\right.$ and 144.9), thirteen methine carbons including four aromatic methine carbons $\left(\delta_{\mathrm{C}} 129.6,116.9,114.5\right.$ and 114.3), five methylene carbons and seven methyl carbons (Table 1).
This NMR spectroscopic data indicated that 1 contained a tricyclic core and its' planar structure closely resembled neodebromoaplysiatoxin A. ${ }^{14}$ Careful analysis of these two compounds' 1D and 2D NMR spectroscopic data uncovered that an oxygenated quaternary carbon resonance of $\delta_{\mathrm{C}} 75.7$ at C-4 in neo-debromoaplysiatoxin A was replaced by the methine resonances of $\delta_{\mathrm{C}} 40.4 / \delta_{\mathrm{H}} 3.29 \mathrm{in} 1$. The HMBC correlations from $\mathrm{H}-4$ to $\mathrm{C}-3$ and C-5 in $\mathbf{1}$ strongly support this assignment (Fig. 2). The NOESY experiments and vicinal coupling constants were utilized to establish its relative stereochemistry. The large coupling constants of $\mathrm{H}-5 \beta(J=13.4,10.6 \mathrm{~Hz})$ and the NOESY cross-peak of $\mathrm{H}-2 / \mathrm{H}_{3}-24$ discovered that $\mathrm{H}-2,4,5 \beta$ and 24 were axially oriented. ${ }^{10,11}$ The NOESY correlations from $\mathrm{H}-5 \beta$ to $\mathrm{H}_{3}-25$ and $\mathrm{H}_{3}-26$ suggested these protons were $\beta$-orientated, whereas the $\alpha$-orientation was indicated at $\mathrm{H}-5 \alpha, \mathrm{H}-2, \mathrm{H}-4$ and $\mathrm{H}_{3}-24$, supported by the NOESY correlations of $\mathrm{H}-2 / \mathrm{H}_{3}-24$ and the large coupling constants of $\mathrm{H}-5 \beta(J=13.4,10.6 \mathrm{~Hz}){ }^{10,11}$ The coupling constants of $\mathrm{H}-11(J=10.8,1.6 \mathrm{~Hz})$ and the NOESY correlation of $\mathrm{H}-12 / \mathrm{H}-11 / \mathrm{H}_{3}-23$ indicated that $\mathrm{H}-10$ and $\mathrm{H}-11$ were anti orientated $\left(J_{\mathrm{H}-10, \mathrm{H}-11}=10.8 \mathrm{~Hz}\right.$ and $\left.J_{\mathrm{H}-11, \mathrm{H}-12}=1.6 \mathrm{~Hz}\right)$. The NOESY cross-peaks of $\mathrm{H}-11 / \mathrm{H}_{3}-23$ indicated these protons were co-facial, while the NOESY correlations of $\mathrm{H}-9 / \mathrm{H}-10$ uncovered these hydrogens were the same side of the cyclohexane, the small coupling between $\mathrm{H}-12$ and $\mathrm{H}-11\left(J_{\mathrm{H}-11, \mathrm{H}-12}=1.6 \mathrm{~Hz}\right)$ and the NOESY correlations of $\mathrm{H}-11 / \mathrm{H}-12 / \mathrm{H}_{3}-23$ and $\mathrm{H}_{3}-22 / \mathrm{H}-10$ established the stereochemistry of C-12 (Fig. 3). The NOESY correlations of $\mathrm{H}_{2}-8 / \mathrm{H}-2$ indicated that the ether oxygen at C-7 was attached axially to the ring A. ${ }^{11}$ Furthermore, taking note of the structural similarities of compounds 1-7, it is likely that these seven compounds have a common biosynthetic origin. ${ }^{13}$ The relative configuration of $\mathrm{C}-29$ and $\mathrm{C}-30$ in the partial structure of 3,4-dihydroxyvaleric acid were consistent with that of the known compounds 4-6 owing to their similar coupling constants between $\mathrm{H}-29$ and $\mathrm{H}-30\left(\mathrm{~J}_{\mathrm{H}-29, \mathrm{H}-30}=4.1 \mathrm{~Hz}\right)$ and biosynthetic pathway. ${ }^{6,10,11}$ Interestingly, 1 was considered as a precursor to neo-debromoaplysiatoxin $\mathrm{A}$ in the plausible biosynthetic pathway of neo-debromoaplysiatoxin A (Scheme $\mathrm{S} 1 \dagger),{ }^{14}$ therefore, we proposed that 1 and neo- 
Table $1{ }^{1} \mathrm{H}(600 \mathrm{MHz})$ and ${ }^{13} \mathrm{C}$ NMR $(150 \mathrm{MHz})$ data for $1-3$ in $\mathrm{CDCl}_{3}(\delta$ in ppm, $\mathrm{J}$ in $\mathrm{Hz})$

\begin{tabular}{|c|c|c|c|c|c|c|}
\hline \multirow[b]{2}{*}{ No. } & \multicolumn{2}{|l|}{1} & \multicolumn{2}{|l|}{2} & \multicolumn{2}{|l|}{3} \\
\hline & $\delta_{\mathrm{H}}(J$ in $\mathrm{Hz})$ & $\delta_{\mathrm{C}}$, type & $\delta_{\mathrm{H}}(J$ in $\mathrm{Hz})$ & $\delta_{\mathrm{C}}$, type & $\delta_{\mathrm{H}}(J$ in $\mathrm{Hz})$ & $\delta_{\mathrm{C}}$, type \\
\hline $1 \alpha$ & & $170.9, \mathrm{qC}$ & & 169.6, qC & $2.50, \mathrm{~d}(13.5)$ & $47.8, \mathrm{CH}_{2}$ \\
\hline $1 \beta$ & & & & & $2.38, \mathrm{~d}(13.5)$ & \\
\hline 2 & $3.24, \mathrm{~s}$ & $62.8, \mathrm{CH}$ & $3.84, \mathrm{~s}$ & $64.4, \mathrm{CH}$ & & $212.4, \mathrm{qC}$ \\
\hline 3 & & $211.6, \mathrm{qC}$ & & $205.9, \mathrm{qC}$ & $2.56, \mathrm{~m}$ & 41.4, CH \\
\hline $4 \beta$ & $3.29, \mathrm{~m}$ & $40.4, \mathrm{CH}$ & $2.60, \mathrm{~m}$ & $41.2, \mathrm{CH}$ & $1.71, \mathrm{dd}(14.0,6.8)$ & $44.3, \mathrm{CH}_{2}$ \\
\hline $4 \alpha$ & & & & & 1.31, dd $(14.2,11.5)$ & \\
\hline $5 \beta$ & $2.33, \mathrm{dd}(13.4,10.6)$ & $43.8, \mathrm{CH}_{2}$ & $1.65, \mathrm{dd}(14.0,6.8)$ & $43.7, \mathrm{CH}_{2}$ & & $38.6, \mathrm{qC}$ \\
\hline $5 \alpha$ & $1.13, \mathrm{~m}$ & & 1.35 , dd $(14.0,13.4)$ & & & \\
\hline 6 & & $40.8, \mathrm{qC}$ & & $40.6, \mathrm{qC}$ & & 79.7, qC \\
\hline 7 & & $78.4, \mathrm{qC}$ & & $81.5, \mathrm{qC}$ & 5.39, dd $(10.3,2.8)$ & 128.1, CH \\
\hline 8 & $2.03, \mathrm{~d}(3.2)$ & $33.3, \mathrm{CH}_{2}$ & 5.45, dd $(10.4,2.9)$ & 125.4, $\mathrm{CH}$ & 5.58, dd $(10.3,1.7)$ & 133.6, CH \\
\hline 9 & $5.01, \mathrm{~m}$ & 73.0, CH & 5.74, dd $(10.4,1.7)$ & 134.2, $\mathrm{CH}$ & $2.12, \mathrm{~m}$ & $30.3, \mathrm{CH}$ \\
\hline 10 & $1.63, \mathrm{~m}$ & $33.1, \mathrm{CH}$ & $2.09, \mathrm{~m}$ & $30.1, \mathrm{CH}$ & 3.05, dd $(9.5,1.8)$ & $75.5, \mathrm{CH}$ \\
\hline 11 & 4.00, dd $(10.8,1.6)$ & $71.7, \mathrm{CH}$ & 2.96, dd $(9.5,1.8)$ & $77.9, \mathrm{CH}$ & 1.61, overlap & $33.7, \mathrm{CH}$ \\
\hline 12 & $1.48, \mathrm{~m}$ & $34.4, \mathrm{CH}$ & 1.55 , overlap & $34.1, \mathrm{CH}$ & $1.33, \mathrm{~m} 1.27, \mathrm{~m}$ & $30.2, \mathrm{CH}_{2}$ \\
\hline $13 \alpha$ & 1.57, overlap & $31.6, \mathrm{CH}_{2}$ & $1.43, \mathrm{~m}$ & $30.7, \mathrm{CH}_{2}$ & $1.78, \mathrm{~m}$ & $36.1, \mathrm{CH}_{2}$ \\
\hline $13 \beta$ & & & $1.23, \mathrm{~m}$ & & $1.61, \mathrm{~m}$ & \\
\hline $14 \alpha$ & $1.85, \mathrm{~m}$ & $37.3, \mathrm{CH}_{2}$ & $1.78, \mathrm{~m}$ & $35.9, \mathrm{CH}_{2}$ & $3.99, \mathrm{t}(6.6)$ & $84.4, \mathrm{CH}$ \\
\hline $14 \beta$ & 1.57, overlap & & 1.53, overlap & & & \\
\hline 15 & $4.08, \mathrm{~m}$ & $85.4, \mathrm{CH}$ & $4.0, \mathrm{t}(6.6)$ & $84.8, \mathrm{CH}$ & & 144.3, qC \\
\hline 16 & & 144.9, qC & & $144.3, \mathrm{qC}$ & 6.79 , overlap & $119.5, \mathrm{CH}$ \\
\hline 17 & $6.88, \mathrm{~d}(7.6)$ & $116.9, \mathrm{CH}$ & $6.84, \mathrm{~d}(7.6,1.2)$ & 119.3, CH & $7.17, \mathrm{t}(8.0)$ & $129.5, \mathrm{CH}$ \\
\hline 18 & $7.20, \mathrm{t}(7.8)$ & 129.6, CH & $7.20, \mathrm{t}(7.8)$ & 129.6, CH & $6.74, \mathrm{dd}(8.1,2.5)$ & 114.9, CH \\
\hline 19 & $6.75, \mathrm{dd}(8.1,2.5)$ & 114.5, CH & 6.76, dd $(8.0,2.6)$ & 114.7, CH & & 156.4, qC \\
\hline 20 & & 156.6, qC & & 156.1, qC & 6.79 , overlap & 113.5, CH \\
\hline 21 & $6.99, \mathrm{~m}$ & $114.3, \mathrm{CH}$ & 6.81 , brs & $113.8, \mathrm{CH}$ & $0.84, \mathrm{~d}(6.8)$ & $13.4, \mathrm{CH}_{3}$ \\
\hline 22 & $0.89, \mathrm{~d}$ & $13.5, \mathrm{CH}_{3}$ & $0.85, \mathrm{~d}$ & $13.0, \mathrm{CH}_{3}$ & $0.80, \mathrm{~d}(7.2)$ & 16.7, $\mathrm{CH}_{3}$ \\
\hline 23 & $0.75, \mathrm{~d}$ & $13.9, \mathrm{CH}_{3}$ & $0.82, \mathrm{~d}$ & $17.0, \mathrm{CH}_{3}$ & $0.87, \mathrm{~s}$ & $24.9, \mathrm{CH}_{3}$ \\
\hline 24 & $0.79, \mathrm{~s}$ & $25.4, \mathrm{CH}_{3}$ & $1.21, \mathrm{~s}$ & 22.5, $\mathrm{CH}_{3}$ & $1.07, \mathrm{~s}$ & $22.6, \mathrm{CH}_{3}$ \\
\hline 25 & $1.02, \mathrm{~s}$ & $25.1, \mathrm{CH}_{3}$ & $0.88, \mathrm{~s}$ & $24.9, \mathrm{CH}_{3}$ & $1.03, \mathrm{~d}(6.6)$ & $14.9, \mathrm{CH}_{3}$ \\
\hline 26 & $1.10, \mathrm{~d}$ & $15.3, \mathrm{CH}_{3}$ & $1.04, \mathrm{~d}$ & $14.4, \mathrm{CH}_{3}$ & $3.20, \mathrm{~s}$ & $56.7, \mathrm{CH}_{3}$ \\
\hline 27 & & 169.8, qC & $3.56, \mathrm{~s}$ & $51.8, \mathrm{CH}_{3}$ & & \\
\hline $28 \beta$ & 2.80, dd $(15.6,5.9)$ & $37.3, \mathrm{CH}_{2}$ & $3,21, \mathrm{~s}$ & $56.8, \mathrm{CH}_{3}$ & & \\
\hline $28 \alpha$ & $2.64, \mathrm{dd}(15.6,10.3)$ & & & & & \\
\hline 29 & 5.14, ddd $(10.3,5.8,4.1)$ & $76.8, \mathrm{CH}$ & & & & \\
\hline 30 & $3.92, \mathrm{~m}$ & $69.8, \mathrm{CH}$ & & & & \\
\hline 31 & $1.25, \mathrm{~d}$ & $18.3, \mathrm{CH}_{3}$ & & & & \\
\hline 32 & $3.27, \mathrm{~s}$ & $57.4, \mathrm{CH}_{3}$ & & & & \\
\hline
\end{tabular}

debromoaplysiatoxin A may have the same absolute configuration and tentatively assigned as $2 R, 4 S, 7 S, 9 S, 10 S, 11 R, 12 S$, $15 S, 29 R, 30 R$.

Oscillatoxin E (2) was obtained as a white solid, HRESIMS data $\left(\mathrm{m} / z\right.$ 495.2732 $\left.[\mathrm{M}+\mathrm{Na}]^{+}\right)$assign its molecular formula as
$\mathrm{C}_{28} \mathrm{H}_{40} \mathrm{O}_{6}$ with nine degrees of unsaturation. 28 carbon resonances can be observed in ${ }^{13} \mathrm{C}$ and DEPT spectra and six quaternary carbons, twelve methines, three methylenes and seven methyls account for the 28 resonances. After counting one ketone group, one carbonyl carbon, one aromatic ring and two

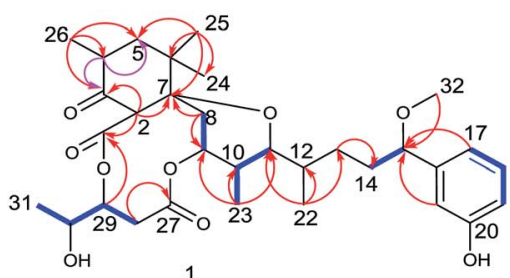

1

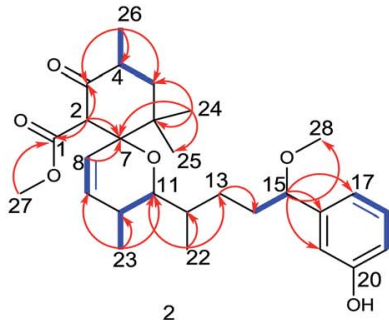

$\overbrace{\mathrm{HMBC}}-$

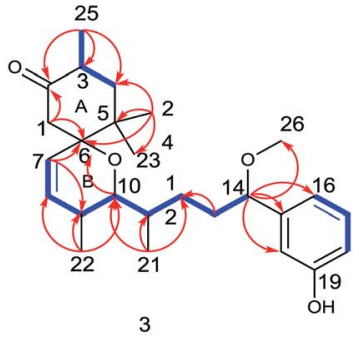

3

Fig. $2{ }^{1} \mathrm{H}-{ }^{1} \mathrm{H}$ key COSY correlations and HMBCs of 1,2 and 3. 


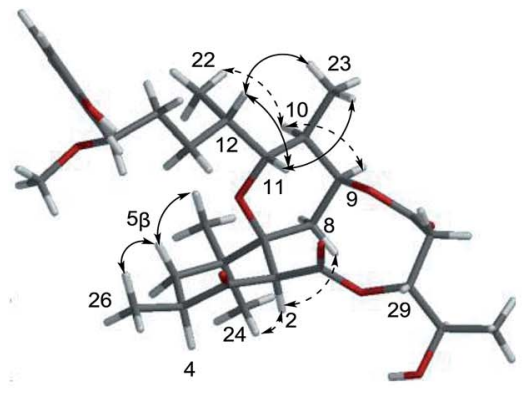

Compound 1

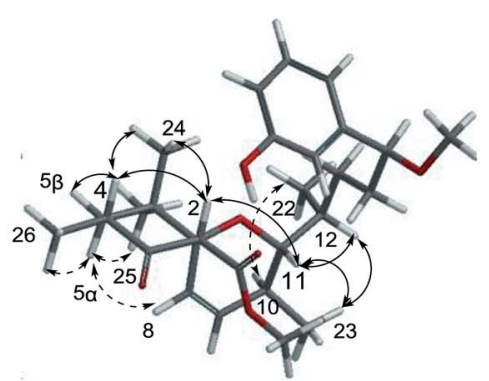

Compound 2

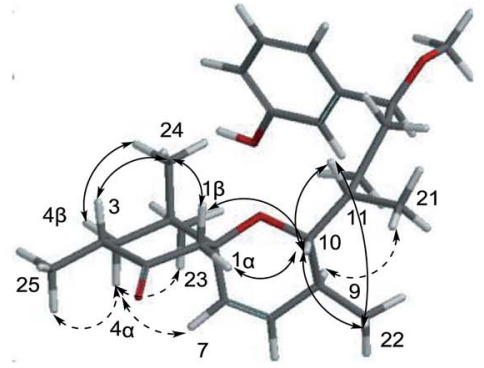

Compound 3

Fig. 3 Key NOESY correlations of 1, 2 and 3.

double bond carbons (Table 1), there are possible two additional rings left to finish nine degrees of unsaturation. The five partial structures, C26-C4-C5, C8-C9, C23-C10-C11, C14-C15 and $\mathrm{C} 17-\mathrm{C} 18-\mathrm{C} 19$, were established by the COSY correlations of $\mathrm{H}_{3}-26 / \mathrm{H}-4 / \mathrm{H}_{2}-5, \mathrm{H}-8 / \mathrm{H}-9, \mathrm{H}_{3}-23 / \mathrm{H}-10 / \mathrm{H}-11, \mathrm{H}_{2}-14 / \mathrm{H}-15$ and $\mathrm{H}-$ 17/H-18/H-19 (Fig. 2). The ring A was closed by the HMBC correlations from $\mathrm{H}-2$ to $\mathrm{C}-3$ and C-7, from $\mathrm{H}_{3}-26$ to C-3, C-4 and $\mathrm{C}-5$ and from $\mathrm{H}_{3}-24$ to $\mathrm{C}-5, \mathrm{C}-6, \mathrm{C}-7$ and C-25. Moreover, the HMBC correlations from $\mathrm{H}_{3}-27$ and $\mathrm{H}-2$ to $\mathrm{C}-1$ positioned the function of $-\mathrm{COOCH}_{3}$ at $\mathrm{C}-2$. The side chain at C-11 (C12-C21) was confirmed by the HMBC correlations from $\mathrm{H}_{3}-22$ to C-11, C12 and $\mathrm{C}-13, \mathrm{H}_{2}-13$ to $\mathrm{C}-14$ and $\mathrm{H}-15$ to $\mathrm{C}-16, \mathrm{C}-17, \mathrm{C}-21$ and C28. The ring $\mathrm{B}$ was established by the HMBC correlations of $\mathrm{H}-8$ / $\mathrm{C} 7, \mathrm{H}_{3}-23 / \mathrm{C}-9, \mathrm{C}-10$ and $\mathrm{C}-11$ and the implications of unsaturation degrees of this molecule completing the planar structure of compound 2 (Fig. 2). Interestingly, the planar structure of compound 2 was closely resembles a synthetic intermediate (22a) of the methyl ethers of 30-methyloscillatoxin D in Yoshihiko Nokura's total synthesis work. ${ }^{17}$ The relative configuration of 2 was identical with that of 22a by the NOESY correlations of $\mathrm{H}-5 \beta / \mathrm{H}-4 / \mathrm{H}-2 / \mathrm{H}_{3}-24, \mathrm{H}-5 \alpha / \mathrm{H}-8, \mathrm{H}_{3}-25$ and $\mathrm{H}_{3}-26, \mathrm{H}-10 / \mathrm{H}_{3}-22, \mathrm{H}-$ $11 / \mathrm{H}-12, \mathrm{H}_{3}-23$ and $\mathrm{H}-2$ and $\mathrm{H}-12 / \mathrm{H}_{3}-23$ (Fig. 3). In addition, the cotton effects at $208 \mathrm{~nm}$ and $276 \mathrm{~nm}$ observed in ECD spectrum of compound 2 were consistent with those of 30-methyloscillatoxin D (7) (Fig. 4). Owing to the common biosynthetic origin of compounds 2 and 7 , as well as the comparative optical rotation values of compound 2 and $22 \mathrm{a}$ (Fig. S37†), the absolute

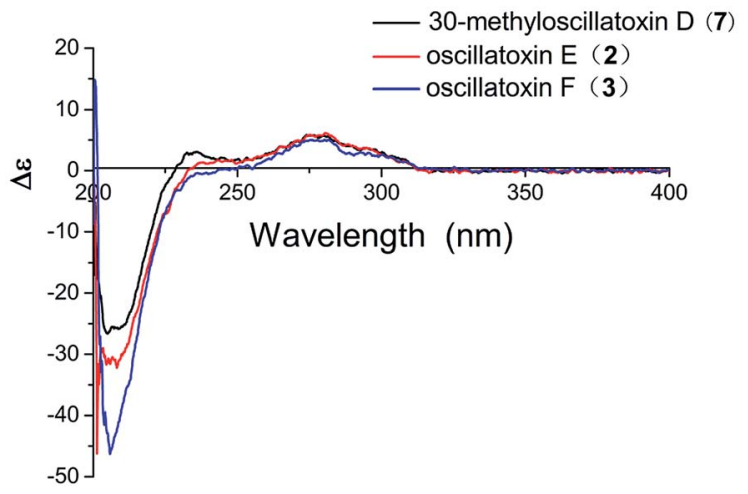

Fig. 4 Experimental ECD spectra of compounds 2, 3 and 7. configuration of 2 was tentatively assigned as $2 S, 4 R, 7 R, 10 S$, $11 R, 12 S$ and $15 S . .^{17,18}$

Oscillatoxin $\mathrm{F}$ (3) was obtained as white solid. The HRESIMS data assigned its molecular formula as $\mathrm{C}_{26} \mathrm{H}_{38} \mathrm{O}_{4}$ showing 58 mass fewer than compound 2. Comparison of $1 \mathrm{D}$ and $2 \mathrm{D}$ NMR spectroscope of compounds 3 and 2 discovered that the additional feature of $-\mathrm{COOCH}_{3}$ at $\mathrm{C}-2$ in 2 was replaced by $\mathrm{H}-1 \alpha$ in 3 , supported by the HMBC correlations from $\mathrm{H}-1 \alpha$ to $\mathrm{C}-2$ and C-7 (Fig. 2 and Table 1). The relative stereochemistry of 3 was deduced from the NOESY spectrum and vicinal coupling constants. The large coupling constants of $\mathrm{H}-4 \alpha(J=14.2,11.5$ $\mathrm{Hz}$ ) and the NOESY correlation of $\mathrm{H}-4 \alpha / \mathrm{H}-7$ discovered that $\mathrm{H}-3$, $\mathrm{H}-4 \alpha$ and the double bond at C-7 were axially orientated. The NOESY correlations of $\mathrm{H}-4 \alpha / \mathrm{H}_{3}-25, \mathrm{H}_{3}-23$ and $\mathrm{H}-7$ and $\mathrm{H}_{3}-24 / \mathrm{H}-$ $1 \beta, \mathrm{H}-3$ and $\mathrm{H}-4 \beta$ indicated that $\mathrm{H}-4 \alpha, \mathrm{H}_{3}-25, \mathrm{H}_{3}-23$ and $\mathrm{H}-7$ were positioned at the opposite side to $\mathrm{H}_{3}-24, \mathrm{H}-1 \beta, \mathrm{H}-3$ and $\mathrm{H}-4 \beta$. In the ring B system, the coupling constants of $\mathrm{H}-10 \mathrm{~J}=$ 9.5, $1.8 \mathrm{~Hz}$ ) and the presence of the NOESY correlation of $\mathrm{H}-11 /$ $\mathrm{H}-10 / \mathrm{H}_{3}-22$ indicated the $\mathrm{H}-10$ and $\mathrm{H}-9$ were anti relationship and $\mathrm{H}-10$ and $\mathrm{H}-11$ were gauche relationship $\left(J_{\mathrm{H}-10, \mathrm{H}-9}=9.5 \mathrm{~Hz}\right.$, $J_{\mathrm{H}-10, \mathrm{H}-11}=1.8 \mathrm{~Hz}$ ). The NOESY correlations of $\mathrm{H}_{3}-22 / \mathrm{H}-10 / \mathrm{H}_{2}-1$ showed that $\mathrm{H}-10, \mathrm{H}_{2}-1$ and $\mathrm{H}_{3}-22$ were on the same side of the ring $\mathrm{B}$, while the small coupling constant of $\mathrm{H}-10 / \mathrm{H}-11\left(\mathrm{~J}_{\mathrm{H}-10, \mathrm{H}-11}\right.$ $=1.8 \mathrm{~Hz}$ ) and the NOESY correlations of $\mathrm{H}-10 / \mathrm{H}-11 / \mathrm{H}_{3}-22$ and $\mathrm{H}_{3}-21 / \mathrm{H}-9$ established the stereochemistry of C-11 (Fig. 3). Moreover, the stereochemistry at $\mathrm{C}-14$ was referred to be $S$ which was same as that of compounds 2 and 7 owing to their positive cotton effects at $275 \mathrm{~nm}$ and common biosynthetic origin. ${ }^{13,14}$ These spectroscopic data established a configuration of $\left(3 R^{*}, 6 S^{*}, 9 S^{*}, 10 R^{*}, 11 S^{*}, 14 S\right)$. The comparison of ECD spectra between $\mathbf{2}, \mathbf{3}$ and 7 suggested they share similar absolute configurations and the absolute configuration of 3 was tentatively assigned as $3 R, 6 S, 9 S, 10 R, 11 S, 14 S$ (Fig. 4).

Following the protocol of previous research, ${ }^{14}$ it was found that all seven compounds did not show significant cytotoxicity at $10 \mu \mathrm{M}$. It has been well studied that aplysiatoxin and its derivatives are activators of protein kinase C (PKC). ${ }^{19,20}$ Therefore, we subsequently assessed compounds 1-7 on the expression of phosphor-PKC $\delta$ in HepG2 cells at $10 \mu \mathrm{M} .{ }^{21}$ Compounds 1 and 4-6 strongly up-regulated the expression of phosphorPKC $\delta$, while the compounds 2, 3 and 7 had no effect (Fig. 5). This difference is possibly due to compounds 2,3 and 7 lacking 
a recognition domain which plays a vital role in intermolecular hydrogen bonding with the PKC $\delta \mathrm{C} 1 \mathrm{~B}$ domain. ${ }^{19}$ Additionally, our previous research has highlighted the potential of aplysiatoxins as ion channel blockers, specifically the selective blocking of Kv1.5. ${ }^{14}$ Following this, we pre-screened our known aplysiatoxin compounds (5-7) for inhibitory activity on the shaker-related subfamily of voltage-gated channels (Kv1.1, Kv1.2, Kv1.3, Kv1.4 and Kv1.5). Our results showed that these three compounds all had significant inhibitory effect on Kv1.5 (Fig. S1.2.2.1†), therefore we expanded our experiment to test metabolites 1-3 and 5-7 for Kv1.5 inhibition, but we did not use compound 4 as the sample amount was unviable. Through this assessment, compounds $2,5,6$ and 7 were seen to exhibit relatively strong inhibitory activity, whereas compounds $\mathbf{1}$ and $\mathbf{3}$ showed weak activities at $1 \mu \mathrm{M}$ (Table S1.2.2†). Oscillatoxin E (2), debromoaplysiatoxin (5), 30-methyloscillatoxin D (7) were chosen to undertake a dose-response study to find their inhibitory value, the results showed that 2,5 and 7 exhibited $\mathrm{IC}_{50}$ values of $0.79 \pm 0.032 \mu \mathrm{M}, 1.28 \pm 0.080 \mu \mathrm{M}$ and $1.47 \pm 0.138$ $\mu \mathrm{M}$, compared to the control compound, acacetin, $5.96 \pm 0.564$ $\mu \mathrm{M}$ (Fig. 6, S1.2.2.2-S1.2.2.5†).

To supplement our knowledge of the interaction between our compounds and the Kv1.5 channel, we performed molecular docking computational analyses. Firstly, we generated a 3D homology model of Kv1.5 using the sequence of Kv1.2 which shares $90 \%$ similarity with our target, especially in the S6 helical domain. We selected resides $480-512$ as the binding pocket as it matched the binding site for the known Kv1.5 channel blocker, vernakalant, which was our positive control. ${ }^{22}$ Vernakalant

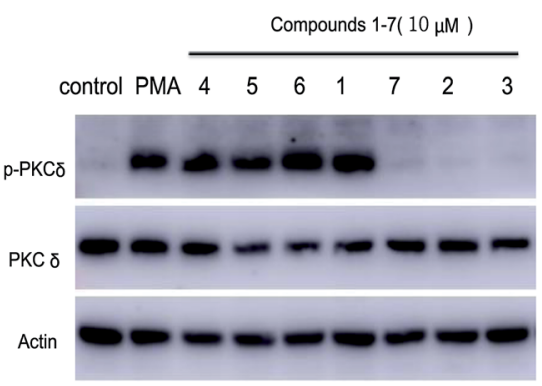

Fig. 5 Effect of compounds 1-7 on phosphor-PKC $\delta$ expression in HepG2 cells.
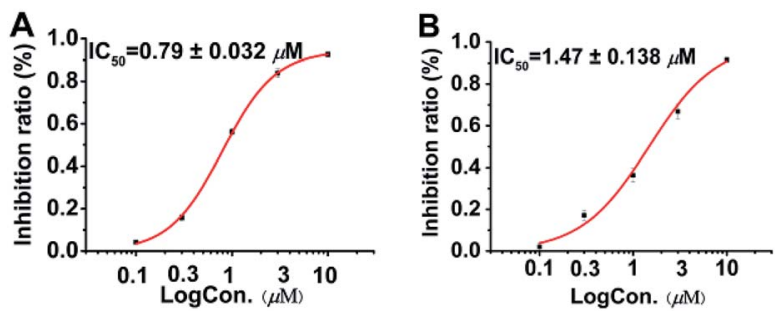

Fig. 6 Dose-response study of 2 and 7 with Kv1.5 expression in $\mathrm{CHO}$ cells at HP of $-80 \mathrm{mV}$. Data points represent mean $\pm \mathrm{SEM}$ of 3 to 5 measurements. Solid curve fits to the Hill equation. (A) Inhibitory effect of 2 showed $\mathrm{IC}_{50}$ value of $0.79 \pm 0.032 \mu \mathrm{M}$. (B) Inhibitory effect of 7 showed IC $C_{50}$ value of $1.47 \pm 0.138 \mu \mathrm{M}$. Acacetin with $I C_{50}$ value of 5.96 $\pm 0.564 \mu \mathrm{M}$ as positive control.

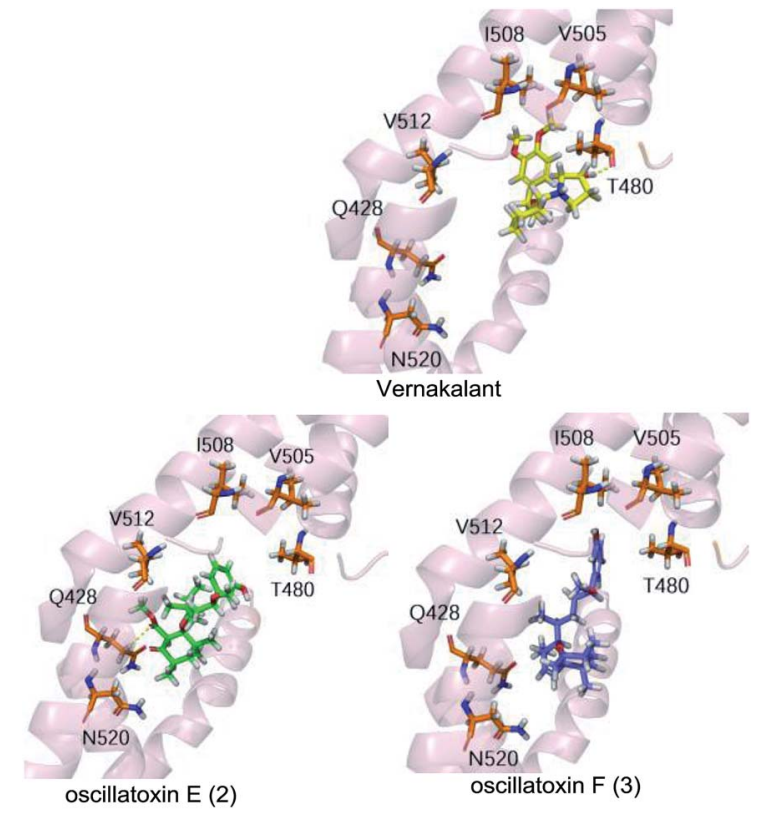

Fig. 7 Molecular docking analysis of between homology models Kv1.5 with Vernakalant, oscillatoxin E (2) and oscillatoxin F (3). Compounds shown as sticks, Homology Kv1.5 channel shown as cartoon, $\mathrm{H}$ bonding interaction represented as yellow dashed line.

shows strong blocking activity against Kv1.5 and is approved in Europe and Canada as an antiarrhythmic agent for the rapid conversion of atrial fibrillation to sinus rhythm. ${ }^{23}$ The docking results showed that vernakalant and oscillatoxin E (2) had strong binding affinities of $-37.374 \quad \mathrm{kcal} \mathrm{mol}^{-1}$, $-37.645 \mathrm{kcal} \mathrm{mol}^{-1}$ but oscillatoxin $\mathrm{F}(3)$ had relatively weaker binding at $-32.217 \mathrm{kcal} \mathrm{mol}^{-1}$ (Table S1.1.1.1†). The difference between the compounds was most likely due to the fact vernakalant and oscillatoxin E (2) had key hydrogen binding interactions (vernakalant : T480, 2 : Q428) however oscillatoxin F (3) did not (Fig. 7). This difference positively reflects our experimental results.

\section{Conclusions}

We successfully isolated several aplysiatoxin analogues which can be grouped into aplysiatoxins (1 and 4-6) and oscillatoxins (2, 3 and 7) based on their structural characteristics. The aplysiatoxins (1 and 4-6) showed strong up-expression of phosphorPKC $\delta$ however the oscillatoxins did not, due to structural frames differences meaning the oscillatoxins lack the specific recognition domain seen in aplysiatoxins. All compounds showed selective blocking of potassium channel Kv1.5 through our preliminary screening assays, furthermore compounds 2 and 7 showed significant inhibitory effect on $\mathrm{Kv} 1.5$ with $\mathrm{IC}_{50}$ values of $0.79 \pm 0.032 \mu \mathrm{M}$ and $1.47 \pm 0.138 \mu \mathrm{M}$. These results should provide helpful advice for researchers in search for new treatment of atrial tachyarrhythmias.

The differences in these compounds further suggest that the activity of voltage-gate potassium channels is modulated by two mechanisms: indirect ion channel modulation by protein phosphorylation and direct ion channel modulation by 
coupling the channels with intracellular signalling enzymes. ${ }^{\mathbf{1 5 , 1 6}}$ Further experimental data is needed to compound this evidence and to discover the exact binding mechanism behind this inhibitors and Kv1.5.

\section{Experimental section}

\section{General experimental procedures}

An Autopol VI polarimeter manufactured by Rudolph Research Analytical, Hackettstown, NJ, USA and a Jasco J-810 spectropolarimeter were used for optical rotations and the ECD spectra, respectively. The NMR experiments were operated on a Bruker Avance 600 spectrometer. HRESIMS data were acquired on an ACQUITYTM UPLC \& Q-TOF MS Premier spectrometer or a Waters Q-TOF micro YAO 19 mass spectrometer. HPLC purification was operated on a waters 1525 series instrument with waters xBridge Prep C-18 column $(5 \mu \mathrm{m}, 10 \mathrm{~mm}$ $\times 250 \mu \mathrm{m}$ ) and a 2998 photodiode array detector.

\section{Material}

The cyanobacterium Lyngbya sp. was collected from the South China Sea in June 2017 and identified by Prof. Bing-Nan Han (Zhejiang Sci-Tech University). A voucher specimen numbered as BNH-201706 has been well stored in Zhejiang Sci-Tech University.

\section{Computational section}

The detailed theoretical calculations of ECD and molecular docking were attached to the ESI. $\uparrow^{24-26}$

\section{Extraction and isolation}

The cyanobacterium (70 g, dry weight) was soaked in $\mathrm{MeOH}$ and $\mathrm{CH}_{2} \mathrm{Cl}_{2}(1: 1, \mathrm{v} / \mathrm{v})$ accompanied by ultrasonic wave to obtained $25.9 \mathrm{~g}$ of extract, which was dissolved in $90 \%$ aqueous $\mathrm{MeOH}$ and extracted with petroleum ether repeatedly. Then the $\mathrm{MeOH}$ fraction was added distilled water to yield $60 \%$ aqueous $\mathrm{MeOH}$ which was partitioned against $\mathrm{CH}_{2} \mathrm{Cl}_{2}$ five times, the $\mathrm{CH}_{2} \mathrm{Cl}_{2}$ soluble fraction ( $3.4 \mathrm{~g}$ ) was subjected to a VLC on silica gel with $n$-hexane-EtoAc $(5: 1,2: 1,1: 1,1: 2,0: 1, \mathrm{v} / \mathrm{v})$ and yield nine fractions (VLC1-9). The fifth part (VLC5) was portioned into 21 subfractions on ODS $\left(10-100 \%, \mathrm{MeCN} / \mathrm{H}_{2} \mathrm{O}, 180 \mathrm{~min}\right)$. The thirteenth and fourteenth fractions were further purified by RPHPLC (YMC-Pack pro C18, $3 \mathrm{~min} \mathrm{~L}^{-1}$, UV detected at $195 \mathrm{~nm}$ ). 4 $\left(20.1 \mathrm{mg}, t_{\mathrm{R}}=26 \mathrm{~min}\right), 5\left(50.0 \mathrm{mg}, t_{\mathrm{R}}=28 \mathrm{~min}\right), 6\left(5.7 \mathrm{mg}, t_{\mathrm{R}}=\right.$ $29 \mathrm{~min})$ and $1\left(2.5 \mathrm{mg}, t_{\mathrm{R}}=25 \mathrm{~min}\right)$ were isolated from the thirteenth part $\left(\mathrm{MeCN} / \mathrm{H}_{2} \mathrm{O}=60: 40\right)$ and $7\left(3.4 \mathrm{mg}, t_{\mathrm{R}}=36\right.$ $\min ), 2\left(3.2 \mathrm{mg}, t_{\mathrm{R}}=40 \mathrm{~min}\right)$ and $3\left(5.1 \mathrm{mg}, t_{\mathrm{R}}=43 \mathrm{~min}\right)$ were purified from the fourteenth fraction $\left(\mathrm{MeCN} / \mathrm{H}_{2} \mathrm{O}=70: 30\right)$.

Neo-debromoaplysiatoxin D (1). Colorless solid; $[\alpha]_{\mathrm{D}}^{25}+16.3$ (c $0.1, \mathrm{MeOH}$ ); ECD (c 0.1, MeOH) $\lambda_{\max }(\Delta \varepsilon) 214$ (-5.52), 275 (1.42) nm; ${ }^{1} \mathrm{H}\left(600 \mathrm{MHz}, \mathrm{CDCl}_{3}\right)$ and ${ }^{13} \mathrm{C} \mathrm{NMR}\left(150 \mathrm{MHz}, \mathrm{CDCl}_{3}\right.$ ) data, Table 1; HRESIMS $m / z$ 597.3040 $[\mathrm{M}+\mathrm{Na}]^{+}$(calcd for $\mathrm{C}_{32} \mathrm{H}_{46} \mathrm{O}_{9} \mathrm{Na}$, 597.3040).

Oscillatoxin E (2). White solid; $[\alpha]_{\mathrm{D}}^{25}-11.3$ (c $\left.0.1, \mathrm{MeOH}\right)$; ECD (c 0.1, MeOH) $\lambda_{\max }(\Delta \varepsilon) 207$ (-31.10), $248(+1.74), 275$ (5.86) nm; ${ }^{1} \mathrm{H}\left(600 \mathrm{MHz}, \mathrm{CDCl}_{3}\right)$ and ${ }^{13} \mathrm{C} \mathrm{NMR}\left(150 \mathrm{MHz}, \mathrm{CDCl}_{3}\right)$ data, Table 1; HRESIMS $m / z$ 495.2732 $[\mathrm{M}+\mathrm{Na}]^{+}$(calcd for $\left.\mathrm{C}_{28} \mathrm{H}_{40} \mathrm{O}_{6} \mathrm{Na}, 495.2723\right)$.

Oscillatoxin F (3). White solid; $[\alpha]_{\mathrm{D}}^{25}-6$ (c 0.15, MeOH); ECD (c $0.1, \mathrm{MeOH}) \lambda_{\max }(\Delta \varepsilon) 206(-46.27), 275$ (5.03) nm; ${ }^{1} \mathrm{H}(600$ $\left.\mathrm{MHz}, \mathrm{CDCl}_{3}\right)$ and $\left.{ }^{13} \mathrm{C} \mathrm{NMR} \mathrm{(150} \mathrm{MHz}, \mathrm{CDCl}_{3}\right)$ data, Table 1; HRESIMS $m / z$ 437.2680 $[\mathrm{M}+\mathrm{Na}]^{+}$(calcd for $\mathrm{C}_{26} \mathrm{H}_{38} \mathrm{O}_{4} \mathrm{Na}$, 437.2688).

\section{Phosphor-PKC $\delta$ assay}

The effects of compounds 1-7 on the phosphorylation of PKC $\delta$ were conducted in HepG2 cells referring to previous protocol. ${ }^{27-29}$ Sententiously, the cells were inoculated in 6-well plates. After $12 \mathrm{~h}$, the cells were treated with compounds (10 $\mu \mathrm{M})$ and PMA $(1 \mu \mathrm{M})$ and incubated for $1 \mathrm{~h}$. Then the cells were lysed with cell lysis buffer. Protein was extracted by BCA protein Assay Kit and determined using western blot.

\section{Ion channel experiment}

The Kv blocking activities of these compounds were determined in CHO cells (Sigma Chemical Co., St. Louis, MO, USA) referring to a reported method. ${ }^{30-32}$ Whole-cell patch-clamp technique was utilized to record the current, the intracellular fluid (KAspartate, $130 \mathrm{mM}$; $\mathrm{MgCl}_{2}$, $5 \mathrm{mM}$; EGTA, $5 \mathrm{mM}$; Hepes, $10 \mathrm{mM}$; Tris-ATP, 4 mM; pH, 7.2 (titrated by $\mathrm{KOH}$ )) was filled electrodes. The cells with density of $80 \%$ were digested by trypsin and translated into $35 \mathrm{~mm}$ Petri dish. The cells were cultured by DMEM/F $12(10 \%$ FBS $+\mathrm{P} / \mathrm{S})$ culture medium in $37^{\circ} \mathrm{C}$ incubator for $5 \% \mathrm{CO}_{2}$. After $24 \mathrm{~h}$, the cells were transferred to the perfusion tank and perfused with extracellular fluid ( $\mathrm{NaCl}, 137 \mathrm{nM}$; $\mathrm{KCl}, 4 \mathrm{nM}$; $\mathrm{CaCl}_{2}, 1.8 \mathrm{nM}$; $\mathrm{MgCl}_{2}, 1 \mathrm{mM}$; HEPES, $10 \mathrm{mM}$; glucose $10 \mathrm{mM}$; pH, 7.4 (titrated by $\mathrm{NaOH}$ )). Compounds were dissolved in DMSO and then added into the extracellular. The holding voltage of cells was set at $-80 \mathrm{mV}$ and the depolarized to $0 \mathrm{mV}$ to obtain currents. This procedure is repeated every 10 seconds. After stabilization, the cells were perfused with the extracellular fluid containing compounds at different concentration and the intensity of blocking was calculated. Data collection and analysis were conducted on pCLAMP 10 (Molecular Devices, Union City, CA).

\section{Conflicts of interest}

There are no conflicts to declare.

\section{Acknowledgements}

This work was supported by the Special Fund for Agro-scientific Research in the Public Interest of Zhejiang province (LGN18C190011), the National Natural Science Foundation of China (Grants 81373321, U1605221), Science Foundation of Zhejiang Sci-Tech University (17042058-Y), Project for Jiaozhou Excellent Innovation Team (18-CX-1), and the National Key Research and Development Program of China (2016YFF0202300, 2018YFC0310900). In addition, we are very grateful to Lawrence Jordan Keen for English correction and revision. 


\section{Notes and references}

1 C. Moreira, V. Ramos, J. Azevedo and V. Vasconcelos, Appl. Microbiol. Biotechnol., 2014, 98, 8073-8082.

2 R. C. Yanagita, H. Kamachi, M. Kikumori, H. Tokuda, N. Suzuki, K. Suenaga, H. Nagai and K. Irie, Bioorg. Med. Chem. Lett., 2013, 23, 4319-4323.

3 M. Kikumori, R. C. Yanagita, H. Tokuda, N. Suzuki, H. Nagai, K. Suenaga and K. Irie, J. Med. Chem., 2012, 55, 5614-5626.

4 M. Suganuma, H. Fujiki, T. Tahira, C. Cheuk, R. E. Moore and T. Sugimura, Carcinogenesis, 1984, 5, 315-318.

5 J. S. Mynderse, R. E. Moore, M. Kashiwagi and T. R. Norton, Science, 1977, 196, 538-540.

6 D. K. Gupta, P. Kaur, S. T. Leong, L. T. Tan, M. R. Prinsep and J. J. Chu, Mar. Drugs, 2014, 12, 115-127.

7 Y. Kato and P. J. Scheuer, J. Am. Chem. Soc., 1974, 5, 22452246.

8 Y. Kato and P. J. Scheuer, Pure Appl. Chem., 1975, 41, 1-14.

9 J. S. Mynderse and R. E. Moore, J. Org. Chem., 1978, 43, 23012303.

10 R. E. Moore, A. J. Blackman, C. E. Cheuk, J. S. Mynderse, G. K. Matsumoto, J. Clardy, R. W. Woodard and J. C. Craig, J. Org. Chem., 1984, 49, 2484-2489.

11 M. Entzeroth, A. J. Blackman, J. S. Mynderse and R. E. Moore, J. Org. Chem., 1985, 16, 1255-1259.

12 H. Nagai, T. Yasumoto and Y. Hokama, J. Nat. Prod., 1997, 60, 925-928.

13 G. E. Chlipala, H. T. Pham, V. H. Nguyen, A. Krunic, S. H. Shim, D. D. Soejarto and J. Orjala, J. Nat. Prod., 2010, 73, 784-787.

14 B. N. Han, T. T. Liang, L. J. Keen, T. T. Fan, X. D. Zhang, L. Xu, Q. Zhao, S. P. Wang and H. W. Lin, Org. Lett., 2018, 20, 578-581.

15 J. Feng, B. Wible, G. R. Li, Z. Wang and S. Nattel, Circ. Res., 1997, 80, 572-579.

16 D. Fedida, J. Physiol., 1997, 499(Pt 3), 661-675.
17 Y. Nokura, Y. Araki, A. Nakazaki and T. Nishikawa, Org. Lett., 2017, 19, 5992-5995.

18 J. Wang, F.-R. Mu, W.-H. Jiao, J. Huang, L.-L. Hong, F. Yang, Y. Xu, S.-P. Wang, F. Sun and H.-W. Lin, J. Nat. Prod., 2017, 80, 2509-2514.

19 Y. Ashida, R. C. Yanagita, C. Takahashi, Y. Kawanami and K. Irie, Bioorg. Med. Chem., 2016, 24, 4218-4227.

20 F. H. Kong, Y. Kishi, D. Perez-Sala and R. R. Rando, Proc. Natl. Acad. Sci. U. S. A., 1991, 88, 1973-1976.

21 A. C. Newton, Chem. Rev., 2001, 101, 2353-2364.

22 J. Eldstrom, Z. Wang, H. Xu, M. Pourrier, A. Ezrin, K. Gibson and D. Fedida, Mol. Pharmacol., 2007, 72, 1522-1534.

23 D. Roy, B. H. Rowe, I. G. Stiell, B. Coutu, J. H. Ip, D. Phaneuf, J. Lee, H. Vidaillet, G. Dickinson, S. Grant, A. M. Ezrin and G. N. Beatch, J. Am. Coll. Cardiol., 2004, 44, 2355-2361.

24 H. Jiang, R. Deng, X. Yang, J. Shang, S. Lu, Y. Zhao, K. Song, X. Liu, Q. Zhang, Y. Chen, Y. E. Chinn, G. Wu, J. Li, G. Chen, J. Yu and J. Zhang, Nat. Chem. Biol., 2017, 13, 994-1001.

25 Q. Shen, F. Cheng, H. Song, W. Lu, J. Zhao, X. An, M. Liu, G. Chen, Z. Zhao and J. Zhang, Am. J. Hum. Genet., 2017, 100, 5-20.

26 J. Li, L. Sun, C. Xu, F. Yu, H. Zhou, Y. Zhao, J. Zhang, J. Cai, C. Mao, L. Tang, Y. Xu and J. He, Acta Biochim. Biophys. Sin., 2012, 44, 300-306.

27 H. Kim, R. Zamel, X.-H. Bai and M. Liu, PLoS One, 2013, 8, e64182.

28 H. Xiao, X. H. Bai, A. Kapus, W. Y. Lu, A. S. Mak and M. Liu, Mol. Cell. Biol., 2010, 30, 5545-5561.

29 B. Han, X. H. Bai, M. Lodyga, J. Xu, B. B. Yang, S. Keshavjee, M. Post and M. Liu, J. Biol. Chem., 2004, 279, 54793-54801.

30 J. Yu, M. H. Park and S. H. Jo, Eur. J. Pharmacol., 2015, 746, 158-166.

31 I. Jeong, S. H. Yoon and S. J. Hahn, Naunyn-Schmiedeberg's Arch. Pharmacol., 2012, 385, 707-716.

32 B. H. Choi, J.-S. Choi, S.-W. Jeong, S. J. Hahn, S. H. Yoon, Y.-H. Jo and M.-S. Kim, J. Pharmacol. Exp. Ther., 2000, 293, 634-640. 